\title{
Motivating Collaborative Consumption in Fashion: Consumer Benefits, Perceived Risks, Service Trust, and Usage Intention of Online Fashion Rental Services
}

\author{
Sae Eun Lee ${ }^{1}$, Hye Jung Jung ${ }^{2, *}$ and Kyu-Hye Lee ${ }^{1, *(D)}$ \\ 1 Human-Tech Convergence Program, Department of Clothing and Textiles, Hanyang University, \\ Seoul 04763, Korea; bion0814@hanmail.net \\ 2 Da Vinci College of General Education, Chung-Ang University, Seoul 06974, Korea \\ * Correspondence: jayjung@cau.ac.kr (H.J.J.); khlee@hanyang.ac.kr (K.-H.L.)
}

Citation: Lee, S.E.; Jung, H.J.; Lee, K.-H. Motivating Collaborative Consumption in Fashion: Consumer Benefits, Perceived Risks, Service Trust, and Usage Intention of Online Fashion Rental Services. Sustainability 2021, 13, 1804. https://doi.org/ $10.3390 /$ su13041804

Academic Editor:

Manfred Max Bergman

Received: 4 January 2021

Accepted: 31 January 2021

Published: 7 February 2021

Publisher's Note: MDPI stays neutral with regard to jurisdictional claims in published maps and institutional affiliations.

Copyright: (c) 2021 by the authors. Licensee MDPI, Basel, Switzerland. This article is an open access article distributed under the terms and conditions of the Creative Commons Attribution (CC BY) license (https:/ / creativecommons.org/licenses/by/ $4.0 /)$.

\begin{abstract}
This study explored the conceptual constructs of consumer benefits and perceived risks of online fashion rental services (Online FRS) and their impacts on usage intention towards Online FRS. The mediating roles of perceived risks and service trust were examined in this research. A survey was performed on female shoppers between the ages of 20-30 residing in a metropolitan area. Results of this research were as follows: (1) The results analyzing the sub-dimension of benefits (Reasonable cost, Wearing at right time, place and occasion (TPO), Space Saving, Entertaining, Product Variety, Style Conformity) and perceived risks (Financial, Performance, Social) clearly presented factorial structures. (2) Reasonable cost, Style Conformity, and Product Variety showed significantly positive influences on usage intentions towards online fashion rental services; in addition, Financial, Performance, and Social risks of rental services had a negative effect on usage intentions. (3) Service trust and consumer perceptions of Financial and Performance risks had important mediating roles in the relationship between consumer benefits and usage intentions towards Online FRS. This study highlighted that consumer benefits, perceived risks, and service trust should be registered among consumers to boost usage intentions towards Online FRS.
\end{abstract}

Keywords: collaborative fashion consumption; online fashion rental services; benefits; perceived risk; trust; usage intention

\section{Introduction}

As global warming and resource depletion are raised as problems of reckless modern consumption, the transition to sustainable consumption is urgently needed. In addition, interest in future safety has grown. Furthermore, green consumption, sustainable consumption, and environmental, social and governance (ESG) factors have continued to draw high attention. In the 2020 World Economic Forum (WEF), along with the COVID-19 lockdown issue, "sustainable consumption" and "saving the plant" factors appeared as major agendas [1].

In these circumstances, various alternatives for sustainable consumption are emerging, and one of them is the sharing economy. The $2020 \mathrm{WEF}$ also noted that "the public will rent everything" and focused on the sharing economy as an alternative to sustainable consumption in all industries [1]. Recently, interest is increasing in the sharing economy that pursues value in use rather than ownership, and in marketing cases that apply it in practice. According to The Economist, the sharing economy market size is expected to reach $£ 216$ billion by 2030, and more than 80 million people will use a sharing economy service [2]. The sharing economy is ultimately an economic activity that contributes to an increase in the profits of the community and the alternative social movement and is used in various forms, such as cooperative consumption [3] and the circular economy [4]. Leggis [5] (2008) defined the sharing economy as "collaborative consumption made by 
the activities of sharing, exchanging, and rental of resources without owning the goods" (p. 143). In addition, Belk [6] defined the term as follows: "Collaborative consumption is people coordinating the acquisition and distribution of a resource for a fee or other compensation" (p. 1597). This refers to sharing products or assets such as cars (Uber, Grab) and homes (Airbnb, Couch surfing) with others for a fee. Sharing economy marketing has recently evolved into a social economic model based on the Internet and smartphones. In the overseas fashion industry, it has continued to emerge and grow in many forms, such as Rent the Runway (New York, NY, USA), Lending Luxury (Tampa, FL, USA), Share Wardrobe (Delhi, India), Secoo Holdings Limited (Beijing, China), Dress \& Go (Sao Paulo, Brazil), and Girls Meet Dress (London, UK). In addition, a service that allows people to rent clothing and accessories at a fixed cost for a certain period of time is drawing attention. According to Future Market Insights, the global online clothing rental market is expected to be valued at $\$ 1952.4$ million in 2026 [7]. Rent the Runway is building its momentum with $\$ 125$ million funding in 2019 [8]. In addition, in modern society where overproduction, overconsumption, and disposal persist, various problems have brought skepticism to consumers; they are pursuing life satisfaction by consuming more meaningful resources through voluntary simplification or reduction in unnecessary consumption. In the case of Korean consumers, $95.5 \%$ are aware of environmental pollution and garbage issues and $82.2 \%$ are likely to purchase sustainable products in the future [9].

Therefore, in the future, consumers will confirm the potential of the rental market for optimizing resources and reducing unnecessary consumption compared to clothing purchase marketing. However, the consumers' experience of using a fashion rental service does not necessarily lead to the final decision to use it. Due to a shift in the paradigm, there is a consistent reduction in ownership and an immense rise in the probability of fashion rental services; however, the shift is not being well activated. It is necessary to examine this issue in terms of the lack of understanding of fashion rental services and use by consumers.

The fashion sharing economy also exhibits various aspects, including donations, second-hand transactions, and rental services; however, studies of the characteristics of each aspect are rare. We should know the characteristics of each aspect of the fashion sharing economy and accordingly establish desirable marketing strategies. Therefore, in this study, based on the sharing/exchange continuum of Habibi et al. [10], which aimed to present the right marketing strategy by examining the characteristics of the sharing economy, we identified types and characteristics in the fashion sharing economy. This helped to present a clear marketing strategy for fashion rental services. Additionally, the user experience of a fashion rental service could lead to a final decision to spend if we examine the barriers and activators that encourage consumers not to use rental services more often. This study aimed to examine the application of the sharing economy in the fashion industry based on the sharing/exchange continuum, identify the perceived benefits and risks of fashion rental services, and present strategies for continuous use by consumers. By understating marketing application cases and consumers' perceptions of the fashion sharing economy, the collaborative consumption of fashion consumers, companies and others can be established as a positive model of sustainable consumption. In addition, this could help to implement efficient merchandising and communication strategies in the fashion sharing economy. Through this study, we aimed to investigate and understand the sharing economy from the perspective of the fashion industry and make contributions by analyzing this new market concept. This could also provide various marketing implications for fashion sharing companies.

\section{Literature Review}

\subsection{Fashion Rental Service}

\subsubsection{The Sharing/Exchange Continuum}

Belk [6] examined the concept of the sharing economy by dividing it into pure sharing and pseudo-sharing, and Habibi et al. Ref. [10] expanded this to the sharing/exchange continuum. This was done to present accurate guidelines to companies that have experienced 
many failures by implementing indiscriminate sharing economy marketing strategies without an accurate understanding of the sharing economy. The sharing/exchange continuum helps to efficiently utilize marketing resources based on clear understanding by identifying the characteristics of real altruistic sharing, economy exchange and the middle concept of dual mode sharing (pseudo-sharing). The sharing/exchange continuum indicates how much non-ownership consumption consists of attributes related to sharing. Pure sharing reflects features such as nonreciprocity, social links, monetary irrelevance, network inclusion, dependence, love and caring. In contrast, pure exchange reflects features such as reciprocity, balanced exchange, monetary relevance, calculation, and independence. Pseudo-sharing is located in the middle, for example Couchsurfing is close to pure sharing, Zipcar is close to pure exchange, and Airbnb is located in the middle. The sharing/exchange continuum was used in the sharing economy research by Fairbnb (accommodation rental service company), research into startups, home industry [11-13] and studies in sustainability [14-16]. Therefore, if we identify the types of fashion sharing such as donation, second-hand use, and rental services, and analyze their characteristics based on the sharing/exchange continuum, this will help to establish an efficient marketing strategy.

\subsubsection{The Fashion Sharing Economy}

\section{- Fashion donation}

As clothing waste has increased and is posing a global problem, consumers have begun to pay attention to donation and disposal of clothing in many ways. In view of the characteristics of the sharing economy shown by fashion donation, as a result of examining used clothing donation, many studies have approached this via the dimension of the circular economy and consumer disposal. The circular economy is mainly based on the approach of recycling through donation of clothes in a sustainable manner, and in research on consumer disposal. The search for consumers' motivation for donation is the main focus. Most of the reasons for clothing donation in the circular economy are found to be based on sustainability and environmental values. For example, the flooding of fast fashion has brought about environmental problems, so we see donation to increase clothing lifespan $[17,18]$ and donation prompted by environmental values and social behaviors $[19,20]$. Therefore, it can be confirmed that fashion donation has the characteristics of nonreciprocity, money irrelevance, singular objects, de facto sharing, and ownership within the sharing/exchange continuum. In the study of clothing donation and consumer disposal, motivation is identified in two aspects: self-oriented and other-oriented [18]. The self-oriented reason for clothing donation behavior leads to more closet space and guilt-free feelings [21]. Other-oriented reasons relate to environmental, economic, charity, and social responsibility factors [19,22]. In their study, Cruz-Cárdenas et al. [23] found that fashion donation strengthens the links between givers and receivers, indicating the strengthening of social bonds. Through this, the characteristics of the sharing/exchange continuum, as seen in the case of clothing donation, include dependence, love and caring, and social bonding. Therefore, fashion donation can be confirmed as close to pure sharing, and hence fashion donation companies should develop marketing strategies related to social links, nonreciprocity, and love and caring.

\section{- Second-hand clothing}

Second-hand clothing relates to sustainability in terms of eco-friendliness. By expanding clothing lifespan, it increases the consumption stage and delays disposal in order to enable sustainable consumption. Research on second-hand clothing focuses on consumer motivation and barriers. There are three motivations for buying second-hand clothing: the first motivation is fashion [24]. Second-hand clothing has uniqueness and difference in appearance that differentiates it from current fashion. In order words, nostalgia exists; moreover, there is also luxury second-hand clothing; it has an authenticity that can satisfy consumers' needs for uniqueness and their hedonic needs $[25,26]$. The second motivation is the economy factor. The consumer is motivated to choose to buy second-hand clothing 
because it is much cheaper than buying a new product $[19,27,28]$. The last reason is sustainability. Many consumers choose second-hand clothing because they are aware of prolonged use for environmental and ecological reasons due to limited resources and environmental impact $[25,29]$. In the case of a personal second-hand clothing swap, pleasure, socializing, friendship and love are also seen as additional reasons $[29,30]$. This confirms that the characteristics of the sharing/exchange continuum include social links, dependence, a sharing context, and love and caring. The barriers that stop consumers from buying second-hand clothing include hygiene risk, performance risk and social risk. It can be seen as a psychological and economic risk when quality is lower than expected or when style and social image makes the consumer out of fashion. Other barriers include contextual barriers, such as unattractive store ambience and product mix [31]. It can be confirmed that calculation, money relevance, and reciprocity exist as barriers, in addition to the sharing/exchange continuum shown above, in the motivation for buying second-hand clothing. Therefore, it can be seen that second-hand clothing is closer to pure exchange than fashion donation. Thus, second-hand clothing companies will have to come up with two complementary marketing strategies, rather than focusing on social links, love and caring aspects, based on monetary relevance and reciprocal aspects.

- Fashion rental service

The commercial sharing economy service, or rental service, is a mixed form of consumption and consumption control that satisfies the desire for consumption while providing the means to use one's own resources to a minimum [32]. There are two types of study on fashion rental services, namely service for luxury fashion goods and for general fashion goods, and it can be seen that there are differences in the reasons for consumers' use of each service (see Table 1). The common reasons for using fashion rental services are economy and sustainability. A study of luxury rental services showed that they are used for hedonic, conspicuous, and self-expressive reasons [33,34]. On the other hand, general fashion rental services are used for functional and fashion reasons. It turns out that both fashion rental services incur costs and provide benefits, such as showing off and economic display. In other words, it is understood that fashion rental services are closer to pure exchange than other aspects of the fashion sharing economy. The sharing/exchange continuum that has emerged has the characteristics of pure exchange with reciprocity, absence of social bonds and joint ownership, monetary relevance, calculation, independence, and balanced exchange. At the same time, a sharing economy aspect exists in terms of social production and non-ownership. Therefore, it can be confirmed that this is a pseudo-sharing economy and close to pure exchange, like Zipcar. Therefore, in this case, it is necessary to develop a higher form of pure exchange marketing strategy than the in the previous two aspects of the fashion sharing economy.

Table 1. Differences in reasons for using luxury and normal fashion rental services.

\begin{tabular}{|c|c|c|}
\hline Luxury Fashion Rental Service & vs & Normal Fashion Rental Service \\
\hline $\begin{array}{c}\text { economic } \\
\text { sustainable }\end{array}$ & & economic \\
\hline self-expressive & & sustainable \\
\hline hedonic & & functional \\
\hline conspicuous & & fashionable \\
\hline
\end{tabular}

\subsection{Backgroud Theories for Fashion Rental Services}

In this section, the valence framework [35], prospect theory [36], and the organizational trust model [37] are used to explain the use of fashion rental services. The valence framework is used in consumer decision-making to explain purchase or use behavior as perceived risk and benefit. In fashion rental services, the perceived benefit is the increased decision to buy as the expected positive utility, and the perceived risk is to decrease the decision to buy as the expected negative utility. Consumers decide based on the valence 
framework between positive and negative. Consumers want to use a fashion rental service based on the perceived benefit, but the perceived risk makes them hesitate to choose. However, the perceived risk and perceived benefit do not affect the consumer to the same degree. According to prospect theory, consumers have a loss aversion tendency that indicates that their response to loss is greater than the response to profit. Therefore, when consumers use fashion rental services, there is a need to carefully review the reaction to the perceived risk. In addition, Schoorman et al. [37] stated that an individual's trust in another's ability, even though there may be a risk, should be treated as willingness to purchase. Various studies on trust in the sharing economy are found to have a positive impact on consumers' purchasing intentions. An analysis of 45 articles concerning trust in the sharing economy by Ter Huurne et al. [38] demonstrated various mechanisms between the dependent variables, such as reputation, trust in platform, and trust in the interaction experience. Kuswanto et al. [39] also stated that trust appears to have a mediating effect on satisfaction and loyalty in ride-sharing services. Accommodation-sharing research showed that trust has a mediating effect on rental intention [40,41]. Cui and Lim [42] identified that trust has a mediating effect on e-loyalty in online travel shopping. Nadeem et al. [43] claimed that there exists a mediating effect between trust in social commerce and loyalty. Thus, there is a perceived risk, but trust in a fashion rental service will help solidify the selection decision.

\subsection{Perceived Benefit in Fashion Rental Services}

Consumers assess the net gain from the acquisition of products or services in the decisionmaking process $[44,45]$. In other words, consumers determine the gains and losses in the decision to buy or use. The perceived benefit, which is the gain, denotes "the perceived net gains associated with the products or services acquired" [45] (p. 48) and is an important factor in consumers' decision to buy or use; so it is necessary to examine this. Since there is a lack of research on the perceived benefits of fashion rental services, we examined various other rental services along with fashion rental services. First, reasonable cost is a perceived benefit in consumers' perception of economic gain. In previous studies, the most important benefit in the sharing economy is cost saving and utility, that is, economic benefit in addition to environmental benefit $[2,6,46]$. Second, the entertainment benefit refers to the pleasure of consumers through treasure hunting and exclusive experiences while using fashion rental services. Several sharing economy studies show that hedonic benefit, perceived as enjoyment, affects the intention to use [47-50], which is in line with a cross-cultural study of fashion rental services by Lang et al. [51]. Third, regarding wearing at the right time, place, and occasion (TPO), it is said that one can choose the right outfit for the situation. In other words, one can find clothes that fit the TPO and can be worn when needed. Shim and Kim [52] (2004) showed that the suitability of the wearer to the garment does not have a significant effect on purchasing intention, but this study pointed out the need to examine this factor. Fourth, style conformity follows the latest trends despite financial burden, e.g., in fashionable clothing or bags. Jain and Mishra [45] stated that Indian millennials use luxury fashion rental services for conformity and status indulgence. Zhang et al. [53] noticed that fashion consciousness influences the intention to use. Fifth, space saving means making sure that the consumer's closet space and personal space are not overtaken by bulky clothes. Mukendi and Henninger's [54] qualitative approach revealed that rental services can be used because consumers can maintain a limited space and various wardrobes. Finally, product variety indicates that, as information, communication, and logistics technologies develop, more opportunities arise to select a variety of items, and these items can be easily returned. Kathan et al. [55] examined the case of Freshneck, a tie-sharing service company, to analyze the increase in convenience and product variety. $\mathrm{Tu}$ and $\mathrm{Hu}$ [56] stated that a significant variety of clothing will be a priority or in high demand by consumers of fashion rental services. 


\subsection{Perceived Risk in Fashion Rental Services}

Mitchell [57] stated the "perceived risk is more powerful at explaining consumers' behavior since consumers are more often motivated to avoid mistakes than maximize the utility in purchasing" (p. 163). Therefore, among the various perceived risks that appear in the sharing economy that impact on consumers' choices, we examined the perceived risk in fashion rental services. First, financial risk refers to the concern about potential financial losses when a consumer chooses to buy [58]. Lang [59] stated that this is a barrier to fashion renting as some consumers may view borrowing instead of owning as a waste of money because of their concerns about not getting in return sufficient use from what they paid for. In addition, research in the sharing economy showed that financial risk has a negative effect on consumption intention $[49,60]$. Second, performance risk refers to the anxiety about the quality of rental service products. Previous studies have mentioned concerns about the quality of physical clothing that cannnot actually be seen on the web [51,59]. Belk [61] also argued that consumers would be reluctant to deal with various risks caused by contamination and hygiene. Baek and Oh [62] have also raised concerns about contamination after COVID-19. Finally, social risks refer to concerns about being ignored or criticized for using rental products from significant others. Lack of ownership can lead to concerns about the lack of expression of self-identity and social stigma for not properly presenting one's social status. Lang et al. [51] confirmed that in this respect consumers holding a high opinion of others' evaluation do not use fashion rental services due to social risk. Catulli [63] asserted that the inability to express one's identity well when using a sustainable business model has a negative impact.

In addition, in several previous studies, the perceived risk is used as a moderator or mediator. Akrma et al. [64] posited that perceived risk moderates the relationship between perceived functional benefit and satisfaction. Wang et al. [65] suggested that perceived risk negatively moderated the relationship between perceived value and the consumer's willingness to use ride-sharing services. Casidy and Wymer [66] claimed that financial, social, and psychological risks mediate between satisfaction and willingness to pay. Mortimer et al. [67] found that online shopping satisfaction and intention were mediated by trust and perceived risk. In the valence framework, perceived benefit and perceived risk were used as juxtaposed concepts, but it was found that perceived risk mediated between satisfaction and intention or willingness to pay and served as a moderator between perceived benefit or perceived value and the dependent variable. Thus, we proceeded with this research assuming that a mediator is possible between perceived benefit and intention.

\section{Methods}

\subsection{Conceptual Framework and Hypotheis}

This study proposes the following model (see Figure 1), which is comprised of eleven dimensions; six benefits, three perceived risks, service trust, and usage intention towards online fashion rental services, along with our research hypotheses.

Regarding the possibility of empirical correlations between benefits pursued by consumers, perceived benefits, trust, and willingness to use online FRS [68], the following hypotheses are proposed:

Hypothesis (H1). Benefits of online FRS (H1a, Wearing at right TPO; H1b, Reasonable cost; H1c, Product variety; H1d, Space saving; H1e, Entertaining; H1f, Style conformity) have a positive effect on usage intention towards online FRS.

Hypothesis (H2). Benefits of online FRS have a positive effect on perceived risks of online FRS.

Hypothesis (H3). Benefits of online FRS (H3a, Wearing at right TPO; H3b, Reasonable cost; H3c, Product variety; H3d, Space saving; H3e, Entertaining; H3f, Style conformity) have a positive effect on trust in online FRS. 
Hypothesis (H4). Perceived risks of online FRS (H4a, Financial; H4b, Performance; H4c, Social) have a negative effect on usage intention of online FRS.

Hypothesis (H5). Trust in online FRS has a positive effect on usage intention of online FRS.

Hypothesis (H6). Perceived risks of online FRS (H6a, Financial; H6b, Performance; H6c, Social) mediate the relationship between benefits and usage intention.

Hypothesis (H7). Trust in online FRS mediates the relationship between benefits and usage intention.

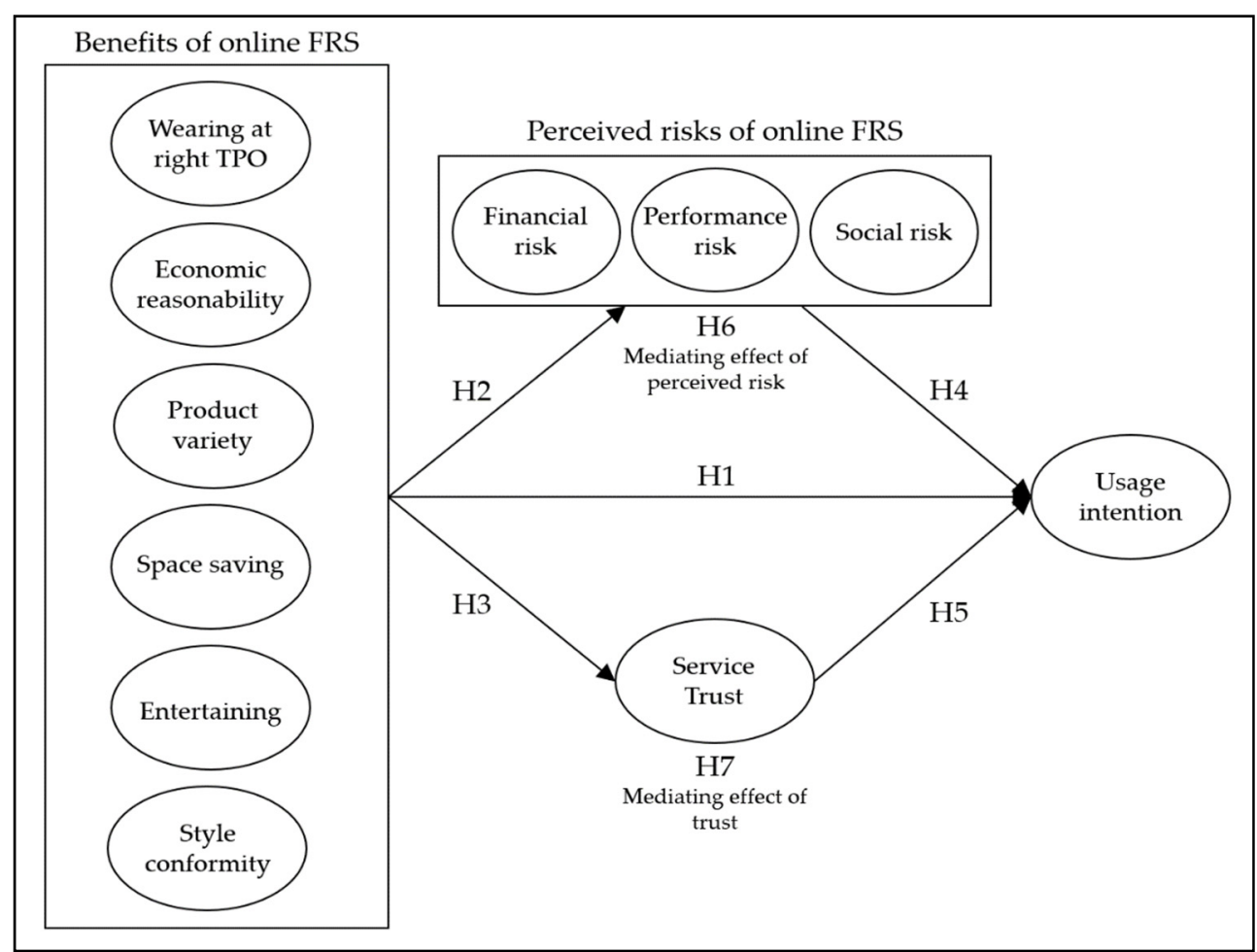

Figure 1. Proposed Theoretical Model.

The definition of research variables in this study is presented in Table 2.

Table 2. Definitions of research variable operability and reference scales.

\begin{tabular}{|c|c|c|}
\hline Research Variables & Definition & Reference \\
\hline Benefit & $\begin{array}{l}\text { This refers to the consumer pursuing the possibility of } \\
\text { positive results through online fashion rental services. }\end{array}$ & $\begin{array}{l}\text { Möhlmann (2015) [69] } \\
\text { Bhatti et al. (2019) [70] }\end{array}$ \\
\hline Perceived risk & $\begin{array}{c}\text { This represents the consumer's predicted risk in using online } \\
\text { fashion rental services. }\end{array}$ & Lang et al. (2019) [51] \\
\hline Service trust & $\begin{array}{l}\text { This indicates the degree to which consumers trust the chosen } \\
\text { services when using online fashion rental services. }\end{array}$ & Papadopoulou et al. (2001) [71] \\
\hline Usage intention & $\begin{array}{l}\text { This refers to the possibility that consumers will } \\
\text { use online fashion rental services. }\end{array}$ & Ajzen (2002) [72] \\
\hline
\end{tabular}

\subsection{Data and Procedure}

The rise in environmental concerns and sustainability has encouraged the emergence of collaborative consumption (CC) models in the fashion industry, such as online platforms for fashion rental services, gaining global force [51]. Though there are several research 
studies on collaborative consumption, most of them have been conducted in Europe and the US [68,73-75]. Empirical research on consumers' opinion of CC in a developing country is still limited. Therefore, respondents in South Korea were recruited for this research. Purposive sampling was utilized, and an online survey was established to collect data. To build a representative sample, a consumer panel of the target population was obtained from a research firm, which asked for responses to an online survey by sending the survey link in an email request. The individuals invited to contribute to the study were pre-validated and had a pre-existing relationship with the firm, and thus they received an incentive from the research firm. After removing inadequate responses, 205 out of 230 returned responses comprised the final sample, with a completion rate of $89.4 \%$.

Data were analyzed by factor analysis, reliability test and descriptive analysis applying SPSS 25.0 package. Structural equation modeling (SEM) was employed to test all hypotheses using AMOS 24.0 version.

\subsection{Measurement}

Multi-item scales were developed to measure the six dimensions of benefits for online FRS. An 18-item scale was modified from Möhlmann [69] and Bhatti et al. [70] to measure consumer benefits from online FRS. Perceived risks of online FRS were measured by a nine-item scale adopted from Lang et al. [51]. Service trust was measured by a three-item scale modified from Papadopoulou et al. [71]. Usage intention towards online FRS was measured using a three-item scale modified from Ajzen [72]. All items were measured utilizing a five-point Likert scale $(1=$ strongly disagree to $5=$ strongly agree). The final section was composed of questions regarding demographic information.

\subsection{Respondents' Characteristics}

As for educational background, most respondents were undergraduate and graduate degree holders $(80.4 \%)$. In terms of marital status, $38.5 \%$ were married and $61.5 \%$ were single. Details are shown in Table 3. The awareness of online fashion rental services was low, but after explaining what collaborative consumption and rental services in fashion are, more than half of the participants responded that the question with sufficient awareness to collaborate meaningfully. In the case of the intention to use fashion rental services, $56.5 \%$ of the total respondents answered that they intended to use.

Table 3. Characteristics and responses of the participants.

\begin{tabular}{ccc}
\hline Variable & Frequency & Percent \\
\hline Age & & \\
$20 \mathrm{~s}$ & 105 & 51.2 \\
$30 \mathrm{~s}$ & 100 & 48.8 \\
\hline Marital status & & 38.5 \\
Married & 79 & 61.5 \\
Single & 126 & 2.0 \\
\hline Highest educational level & 4 & 17.1 \\
Middle school & 35 & 71.1 \\
High school & 147 & 9.3 \\
Undergraduate & 19 & 19.1 \\
Graduate & & 31.2 \\
Awareness of online FRS & 39 & 49.8 \\
Familiar with them & 64 & \\
Have heard about them & 102 & 56.5 \\
Have no idea about them & & 43.4 \\
\hline Yes & 116 & 89 \\
No & &
\end{tabular}


Table 3. Cont

\begin{tabular}{ccc}
\hline Variable & Frequency & Percent \\
\hline Usage experience of online FRS & & 24.9 \\
Yes & 51 & 75.1 \\
No & 154 & $-*$ \\
Previous rent items of online FRS & 41 & - \\
Fashion products for wedding dress, traditional cloths & 17 & - \\
Fashion products for special official meeting or events & 33 & - \\
\hline
\end{tabular}

${ }^{*}$ more than one answer.

\subsection{Construct Validity and Descriptive Statistics}

The descriptive and reliability statistics of all items are shown in Table 4 . In the confirmatory factor analysis (CFA), the overall fit indices, $\chi 2 / \mathrm{df}=1.45, \mathrm{CFI}=0.94, \mathrm{GFI}=0.89$, $\mathrm{TLI}=0.93, \mathrm{NFI}=0.90, \mathrm{RMSEA}=0.04$, indicated an overall fitness of the model [76]. As Hair et al. [77] indicated, the proposed model's reliability and validity were assessed. To test the validity and reliability of the structural equation model, the standard loading value, $\mathrm{t}$-value, $p$-value, standard error, average variance extracted (AVE), composite reliability $(\mathrm{CR})$, and Cronbach's alpha $(\alpha)$ indices were calculated. Table 4 shows the assessment results for convergent validity and the reliability of the measurement model. Since the standard loading values of each construct were 0.6 or higher, and Cronbach's alpha value of each construct was 0.7 or higher with statistical significance, convergent validity was achieved. The range of $\mathrm{CR}$ was from 0.655 to 0.864 , so internal reliability was achieved. The range of standard loading values was from 0.608 to 0.989 , while each construct was statistically significant at $p<0.001$. Cronbach's alpha value ranged from 0.742 to 0.952 , and AVE value ranged from 0.511 to 0.757 .

Table 4. Reliability and Validity of Measures.

\begin{tabular}{|c|c|}
\hline Factors and Items & Loading \\
\hline \multicolumn{2}{|l|}{ Benefits of online FRS } \\
\hline \multicolumn{2}{|l|}{$\begin{array}{l}\text { Wearing at right time, place and occasion }(\mathrm{TPO}) \text { (average variance extracted }(\mathrm{AVE})=0.75 \\
\qquad \mathrm{CR}=0.89 ; \alpha=0.85)\end{array}$} \\
\hline I can attend a meeting wearing clothes suitable for the occasion. & 0.936 \\
\hline I can wear clothes suitable for the purpose of the event when participating in it. & 0.908 \\
\hline I can find and wear clothes or accessories that suit my personality. & 0.749 \\
\hline \multicolumn{2}{|l|}{ Product variety $(\mathrm{AVE}=0.58 ; \mathrm{CR}=0.83 ; \alpha=0.89)$} \\
\hline I can see many fashion products offered in online fashion rental services. & 0.788 \\
\hline I can borrow and wear various fashion products from online fashion rental services. & 0.784 \\
\hline I can find new styles of product that are ahead of fashion from online fashion rental services. & 0.720 \\
\hline \multicolumn{2}{|l|}{ Reasonable cost $(\mathrm{AVE}=0.51 ; \mathrm{CR}=0.87 ; \alpha=0.82)$} \\
\hline I can wear expensive clothes at a low cost. & 0.805 \\
\hline I can wear clothes that I do not usually wear. & 0.695 \\
\hline In the case of clothes that are less frequently worn, I can always wear them neatly if I get them on rent. & 0.624 \\
\hline \multicolumn{2}{|l|}{ Entertaining $(\mathrm{AVE}=0.71 ; \mathrm{CR}=0.89 ; \alpha=0.83)$} \\
\hline Fashion rental service would be a real pleasure. & 0.899 \\
\hline I would enjoy rental clothing. & 0.783 \\
\hline
\end{tabular}


Table 4. Cont.

\begin{tabular}{|c|c|}
\hline Factors and Items & Loading \\
\hline \multicolumn{2}{|l|}{ Style conformity $(\mathrm{AVE}=0.64 ; \mathrm{CR}=0.87 ; \alpha=0.742)$} \\
\hline I can wear clothes that match fast-changing trends. & 0.833 \\
\hline If I participate in an event, I can wear similar styled clothes as other attendees. & 0.764 \\
\hline \multicolumn{2}{|l|}{ Space saving $(\mathrm{AVE}=0.67 ; \mathrm{CR}=0.89 ; \alpha=0.89)$} \\
\hline I can save space in the closet. & 0.939 \\
\hline I have a small number of unnecessary clothes in the closet, so it is easy to manage. & 0.841 \\
\hline \multicolumn{2}{|l|}{ Perceived risk of online FRS } \\
\hline \multicolumn{2}{|l|}{ Financial risk $(\mathrm{AVE}=0.54 ; \mathrm{CR}=0.86 ; \alpha=0.90)$} \\
\hline It will cost a lot to manage and keep the rented clothes in good shape. & 0.797 \\
\hline I will feel that I wasted money to rent clothes just for a short time. & 0.735 \\
\hline I will feel that I wasted money to rent clothes but without owning them. & 0.657 \\
\hline \multicolumn{2}{|l|}{ Performance risk $(\mathrm{AVE}=0.85 ; \mathrm{CR}=0.81 ; \alpha=0.85)$} \\
\hline I am worried about the cleanliness of the rented clothing. & 0.790 \\
\hline I will not feel comfortable when wearing clothes that have been worn by others. & 0.743 \\
\hline It will not be easy to manage and wear the rented clothes clean. & 0.632 \\
\hline \multicolumn{2}{|l|}{ Social risk $(\mathrm{AVE}=0.55 ; \mathrm{CR}=0.75 ; \alpha=0.88)$} \\
\hline I am worried that my friends might think I look weird or funny in rented clothing & 0.743 \\
\hline I will not feel comfortable wearing rented clothing in public. & 0.743 \\
\hline \multicolumn{2}{|l|}{ Trust in online FRS $(\mathrm{AVE}=0.51 ; \mathrm{CR}=0.84 ; \alpha=0.87)$} \\
\hline I do believe that the transaction through this online fashion rental service is reliable. & 0.764 \\
\hline I can say that this online fashion rental service is trustworthy. & 0.699 \\
\hline I do believe that this online fashion rental service protects my best interest. & 0.608 \\
\hline \multicolumn{2}{|l|}{ Usage intention for online FRS $(\mathrm{AVE}=0.71 ; \mathrm{CR}=0.95 ; \alpha=0.92)$} \\
\hline I have an intention to use this online fashion rental service. & 0.878 \\
\hline I am willing to visit the website of this fashion rental service. & 0.865 \\
\hline I am willing to recommend this fashion rental service to other. & 0.776 \\
\hline
\end{tabular}

FRS $=$ Fashion rental services; $\alpha=$ Cronbach's alpha; CFI $=$ Comparative Fit Index; GFI = Goodness-Of-Fit statistic; TLI = Tucker-Lewis Index; NFI = Normed Fit Index; RMSEA = Root Mean Square Error of Approximation.

In this research, discriminant validity was measured using recommendations suggested by Fornell and Larcker [78]. Discriminant validity refers to a state where researchers identify that each indicator of a theoretical model is different in terms of statistics. Discriminant validity can be calculated by using the method in which AVE is compared with squared correlations. Discriminant validity is supported when the AVE between each pair of constructs is greater than $\Phi^{2}$ (i.e., the squared correlation between two constructs) (see Table 5). 
Table 5. Discriminant validity and means of variables.

\begin{tabular}{|c|c|c|c|c|c|c|c|c|c|c|c|c|c|}
\hline & \multirow{2}{*}{ Variables } & \multicolumn{11}{|c|}{ Correlation Coefficient } & \multirow{2}{*}{ Means } \\
\hline & & 1 & 2 & 3 & 4 & 5 & 6 & 7 & 8 & 9 & 10 & 11 & \\
\hline 1 & $\begin{array}{l}\text { Wearing at } \\
\text { TPO }\end{array}$ & $0.75^{\mathrm{a}}$ & & & & & & & & & & & $2.95^{\mathrm{d}}$ \\
\hline 2 & $\begin{array}{l}\text { Product } \\
\text { variety }\end{array}$ & $\begin{array}{c}0.37^{\mathrm{b}} \\
0.61^{* * * \mathrm{c}}\end{array}$ & 0.58 & & & & & & & & & & 3.50 \\
\hline 3 & $\begin{array}{l}\text { Economic } \\
\text { reasonability }\end{array}$ & $\begin{array}{l}0.00 \\
0.06\end{array}$ & $\begin{array}{c}0.03 \\
0.18^{*}\end{array}$ & 0.51 & & & & & & & & & 4.28 \\
\hline 4 & Entertaining & $\begin{array}{c}0.10 \\
0.32 * * *\end{array}$ & $\begin{array}{c}0.16 \\
0.40^{* * *}\end{array}$ & $\begin{array}{c}0.08 \\
0.29 * *\end{array}$ & 0.71 & & & & & & & & 4.07 \\
\hline 5 & $\begin{array}{c}\text { Style } \\
\text { conformity }\end{array}$ & $\begin{array}{c}0.16 \\
0.41^{* * *}\end{array}$ & $\begin{array}{c}0.32 \\
0.57^{* * *}\end{array}$ & $\begin{array}{c}0.18 \\
0.42^{* * *}\end{array}$ & $\begin{array}{c}0.45 \\
0.67^{* * *}\end{array}$ & 0.64 & & & & & & & 4.14 \\
\hline 6 & Space saving & $\begin{array}{c}0.10 \\
0.32^{* * *}\end{array}$ & $\begin{array}{c}0.17 \\
0.41^{* * *}\end{array}$ & $\begin{array}{c}0.11 \\
0.33^{* * *}\end{array}$ & $\begin{array}{c}0.05 \\
0.23 \text { ** }\end{array}$ & $\begin{array}{c}0.04 \\
0.20 \text { * }\end{array}$ & 0.67 & & & & & & 3.57 \\
\hline 7 & $\begin{array}{l}\text { Financial } \\
\text { risk }\end{array}$ & $\begin{array}{c}0.07 \\
-0.28 \text { ** }\end{array}$ & $\begin{array}{c}0.19 \\
0.44^{* * *}\end{array}$ & $\begin{array}{c}0.08 \\
0.28 * *\end{array}$ & $\begin{array}{c}0.17 \\
0.41^{* * *}\end{array}$ & $\begin{array}{c}0.20 \\
0.45^{* * *}\end{array}$ & $\begin{array}{c}0.08 \\
0.29\end{array}$ & 0.54 & & & & & 3.88 \\
\hline 8 & $\begin{array}{l}\text { Performance } \\
\text { risk }\end{array}$ & $\begin{array}{c}0.22 \\
0.47^{* * *}\end{array}$ & $\begin{array}{c}0.16 \\
0.40^{* * *}\end{array}$ & $\begin{array}{c}0.05 \\
0.23 \text { * }\end{array}$ & $\begin{array}{l}0.13^{*} \\
0.35^{* *}\end{array}$ & $\begin{array}{c}0.13 \\
0.36^{* * *}\end{array}$ & $\begin{array}{c}0.04 \\
0.21 *\end{array}$ & $\begin{array}{c}0.51 \\
0.71^{* * * *}\end{array}$ & 0.52 & & & & 3.53 \\
\hline 9 & Social risk & $\begin{array}{c}0.06 \\
0.25\end{array}$ & $\begin{array}{c}0.26 \\
0.51 * * *\end{array}$ & $\begin{array}{c}0.05 \\
0.23\end{array}$ & $\begin{array}{c}0.04 \\
0.19^{*}\end{array}$ & $\begin{array}{c}0.15 \\
0.39^{* * *}\end{array}$ & $\begin{array}{c}0.08 \\
0.29 * *\end{array}$ & $\begin{array}{c}0.41 \\
0.64^{* * *}\end{array}$ & $\begin{array}{c}0.48 \\
0.69^{* *}\end{array}$ & 0.55 & & & 3.65 \\
\hline 10 & Trust & $\begin{array}{c}0.04 \\
0.20 *\end{array}$ & $\begin{array}{c}0.15 \\
0.38^{* * *}\end{array}$ & $\begin{array}{c}0.14 \\
0.38^{* * *}\end{array}$ & $\begin{array}{c}0.05 \\
0.23 *\end{array}$ & $\begin{array}{c}0.07 \\
0.27^{* *}\end{array}$ & $\begin{array}{c}0.11 \\
0.33^{* *}\end{array}$ & $\begin{array}{c}0.19 \\
-0.44 \\
* * *\end{array}$ & $\begin{array}{c}0.50 \\
-0.71 \\
* *\end{array}$ & $\begin{array}{c}0.36 \\
-0.60 \\
* *\end{array}$ & 0.51 & & 4.01 \\
\hline 11 & $\begin{array}{l}\text { Usage } \\
\text { intention }\end{array}$ & $\begin{array}{c}0.05 \\
0.22 * *\end{array}$ & $\begin{array}{c}0.10 \\
0.32 * * *\end{array}$ & $\begin{array}{c}0.08 \\
0.29 * *\end{array}$ & $\begin{array}{c}0.05 \\
0.22 * *\end{array}$ & $\begin{array}{c}0.14 \\
0.37^{* * *}\end{array}$ & $\begin{array}{c}0.04 \\
0.21 *\end{array}$ & $\begin{array}{c}0.52 \\
-0.72 \\
* * *\end{array}$ & $\begin{array}{c}0.16 \\
-0.41 \\
* * *\end{array}$ & $\begin{array}{c}0.21 \\
-0.46 \\
* * *\end{array}$ & $\begin{array}{c}0.22 \\
0.47^{* * *}\end{array}$ & 0.71 & 4.01 \\
\hline
\end{tabular}

Notes: ${ }^{*} p<0.05,{ }^{* *} p<0.01,{ }^{* * *} p<0.001 ;{ }^{a}$ : Average variance extracted (AVE), ${ }^{\text {b }}$ : Squared correlations between any pair of constructs, ${ }^{\mathrm{c}}$ : Correlation coefficients, ${ }^{\mathrm{d}}$ : Mean score $(1=$ strong disagreement, $5=$ strong agreement).

\section{Results}

\subsection{Testing Hypotheis}

Structural equation modeling was conducted to assess the hypothesized relationships. The hypothesis test results are shown in Table 6.

$\mathrm{H} 1$ tested whether benefits of online FRS positively affect usage intention towards online FRS. The hypothesized structural model generated a good fit $(\chi 2(\mathrm{df})=986.82(218)$, $\mathrm{CFI}=0.90, \mathrm{GFI}=0.87, \mathrm{NFI}=0.87, \mathrm{RMSEA}=0.007)$. Four dimensions of benefits $(\mathrm{H} 1 \mathrm{a}$, Wearing at right TPO; H1b, Reasonable cost; H1c, Product variety; H1f, Style conformity) for online FRS positively influenced the usage intention towards online FRS. Reasonable $\operatorname{cost}(\beta=0.30, p<0.001)$, wearing at right TPO $(\beta=0.22, p<0.01)$, product variety $(\beta=0.21$, $p<0.01)$, and style conformity $(\beta=0.18, p<0.05)$ benefits strongly influenced usage intention for online FRS, while there was no significant influence of other two benefits (entertaining and space saving). Consequently, H1a, H1b, H1c, and H1f were supported, indicating that consumers who pursue benefits regarding wearing at right time, place, and occasion, Reasonable cost, product variety and style conformity highly tended to have positive usage intention towards online FRS.

$\mathrm{H} 2$ tested whether benefits had a positive influence on perceived risks. The hypothesized structural model generated a good fit $(\chi 2(\mathrm{df})=318.970(219), \mathrm{CFI}=0.95, \mathrm{GFI}=0.89$, $\mathrm{NFI}=0.89$, RMSEA $=0.04)$. The effects of benefits on reasonable cost $(\beta=0.29, p<0.01)$ and product variety $(\beta=0.24, p<0.01)$ were significant on financial risks. The benefits of reasonable cost $(\beta=0.26, p<0.01)$, product variety $(\beta=0.31, p<0.01)$, entertaining $(\beta=0.20, p<0.05)$, and style conformity $(\beta=0.18, p<0.05)$ were significant for performance risks. The effects of benefits of reasonable cost $(\beta=0.41, p<0.001)$, style conformity $(\beta=0.33, p<0.001)$, and wearing at right TPO $(\beta=0.25, p<0.01)$ were significant for social 
risks. Overall, consumers who engaged in economic saving tended to all perceive financial, performance, and social risks in online FRS.

Table 6. Hypotheses testing results: direct effects.

\begin{tabular}{|c|c|c|c|c|}
\hline Dependent Variable & Explanatory Variable & $B$ & Hypothesis & Testing Results \\
\hline \multirow{6}{*}{ Usage intention } & Wearing to TPO & $0.22 * *$ & H1a & Supported \\
\hline & Reasonable cost & $0.35^{* * *}$ & $\mathrm{H} 1 \mathrm{~b}$ & Supported \\
\hline & Product variety & $0.42 * * *$ & $\mathrm{H} 1 \mathrm{c}$ & Supported \\
\hline & Space saving & Ns & H1d & Not supported \\
\hline & Entertaining & Ns & H1e & Not supported \\
\hline & Style conformity & $0.18 *$ & H1f & Supported \\
\hline \multirow{6}{*}{ Financial risk } & Wearing to TPO & Ns & H2aa & Not supported \\
\hline & Reasonable cost & $0.29 * *$ & $\mathrm{H} 2 \mathrm{ba}$ & Supported \\
\hline & Product variety & $0.24^{* *}$ & $\mathrm{H} 2 \mathrm{ca}$ & Supported \\
\hline & Space saving & Ns & $\mathrm{H} 2 \mathrm{da}$ & Not supported \\
\hline & Entertaining & Ns & H2ea & Not supported \\
\hline & Style conformity & Ns & $\mathrm{H} 2 \mathrm{fa}$ & Not supported \\
\hline \multirow{6}{*}{ Performance risk } & Wearing to TPO & Ns & $\mathrm{H} 2 \mathrm{ab}$ & Not supported \\
\hline & Reasonable cost & $0.26^{* *}$ & $\mathrm{H} 2 \mathrm{bb}$ & Supported \\
\hline & Product variety & $0.31^{* *}$ & $\mathrm{H} 2 \mathrm{cb}$ & Supported \\
\hline & Space saving & ns & $\mathrm{H} 2 \mathrm{db}$ & Not supported \\
\hline & Entertaining & 0.20 * & $\mathrm{H} 2 \mathrm{eb}$ & Supported \\
\hline & Style conformity & $0.18 *$ & $\mathrm{H} 2 \mathrm{fb}$ & Supported \\
\hline \multirow{6}{*}{ Social risk } & Wearing to TPO & $0.25 * *$ & $\mathrm{H} 2 \mathrm{ac}$ & Supported \\
\hline & Reasonable cost & $0.41^{* * *}$ & $\mathrm{H} 2 \mathrm{bc}$ & Supported \\
\hline & Product variety & $\mathrm{ns}$ & $\mathrm{H} 2 \mathrm{cc}$ & Not supported \\
\hline & Space saving & ns & $\mathrm{H} 2 \mathrm{dc}$ & Not supported \\
\hline & Entertaining & ns & $\mathrm{H} 2 \mathrm{ec}$ & Not supported \\
\hline & Style conformity & $0.33^{* * *}$ & $\mathrm{H} 2 \mathrm{fc}$ & Supported \\
\hline \multirow{6}{*}{ Trust } & Wearing to TPO & $\mathrm{ns}$ & $\mathrm{H} 3 \mathrm{a}$ & Not supported \\
\hline & Reasonable cost & $0.34^{* * *}$ & $\mathrm{H} 3 \mathrm{~b}$ & Supported \\
\hline & Product variety & $0.32 * *$ & $\mathrm{H} 3 \mathrm{c}$ & Supported \\
\hline & Space saving & ns & $\mathrm{H} 3 \mathrm{~d}$ & Not supported \\
\hline & Entertaining & ns & H3e & Not supported \\
\hline & Style conformity & $-19 *$ & $\mathrm{H} 3 \mathrm{f}$ & Supported \\
\hline \multirow{3}{*}{ Usage intention } & Financial risk & $-0.34^{* * *}$ & $\mathrm{H} 4 \mathrm{a}$ & Supported \\
\hline & Performance risk & $-0.23^{* *}$ & $\mathrm{H} 4 \mathrm{~b}$ & Supported \\
\hline & Social risk & $-0.21 *$ & $\mathrm{H} 4 \mathrm{c}$ & Not supported \\
\hline Usage intention & Trust & $0.46^{* * *}$ & H5 & Supported \\
\hline
\end{tabular}

Notes: $\beta$, the path coefficient; ${ }^{*} p<0.05,{ }^{* *} p<0.01,{ }^{* * *} p<0.001 ; \mathrm{ns}=$ not statistically significant. Structural model fit indices: H1: $\chi 2(\mathrm{df})=1811.36(234), \mathrm{CFI}=0.93, \mathrm{GFI}=0.85, \mathrm{NFI}=0.87, \mathrm{RMSEA}=0.03 ; \mathrm{H2}: \chi 2(\mathrm{df})=318.970(219), \mathrm{CFI}=0.95, \mathrm{GFI}=0.89, \mathrm{NFI}=0.89$, RMSEA = 0.04; H3: $\chi 2(\mathrm{df})=207.715(131), \mathrm{CFI}=0.96, \mathrm{GFI}=0.90, \mathrm{NFI}=0.89, \mathrm{RMSEA}=0.05 ; \mathrm{H} 4: \chi 2(\mathrm{df})=49.566(38), \mathrm{CFI}=0.99, \mathrm{GFI}=0.96$, $\mathrm{NFI}=0.94, \mathrm{RMSEA}=0.04 ; \mathrm{H} 5: \times 2(\mathrm{df})=13.269(8), \mathrm{CFI}=0.99, \mathrm{GFI}=0.98, \mathrm{NFI}=0.97, \mathrm{RMSEA}=0.06$. 
H3 examined the positive effect of benefits on trust in online FRS. The effects of three benefits on usage intention towards online FRS were significant. Reasonable cost $(\beta=0.34$, $p<0.001)$ and product variety $(\beta=0.32, p<0.01)$ positively affected usage intention towards online FRS, while style conformity $(\beta=-0.19, p<0.05)$ had a negative effect on intention. To improve the degree of trust in online FRS, both reasonable cost and product variety are important regarding online fashion product rental. However, consumers motivated by benefits of style conformity on tended to show lower trust levels towards online FRS.

All paths from the three perceived risks for usage intention towards online FRS products were significant, which proves H4. Financial risks $(\beta=-0.34, p<0.001)$, performance risks $(\beta=-0.23, p<0.01)$, and social risks $(\beta=-0.21, p<0.05)$ had a negative effect on usage intention towards online FRS: therefore, $\mathrm{H} 4 \mathrm{a}, \mathrm{H} 4 \mathrm{~b}$, and $\mathrm{H} 4 \mathrm{c}$ were all supported. In addition, a significantly positive relationship between trust $(\beta=0.46, p<0.001)$ and usage was found; thus, $\mathrm{H} 5$ was supported. To achieve a positive intention to use online FRS, trust is essential.

In sum, 19 of 34 hypotheses were accepted, which indicates that the Benefit-Risk-TrustIntention model would facilitate consumers' collaborative consumption, i.e., renting and sharing fashion items via the online platform.

\subsection{The Mediating Effect of Perceived Risks and Trust}

This study has four mediating hypotheses (H6a, financial risk; H6b, performance risk; H6c, social risk; H7, trust). To test the mediating role of perceived risk and trust in relation to benefits and usage intention towards online FRS, this study followed the process proposed by Cohen et al. [79]. In validation of the mediating roles, the constrained and nonconstrained models in the path between latent variables were established and the $\chi 2$ value difference between the two models was examined to find whether the non-concentrated model has statistically improved model fit over the concentrated model. The difference in the degree of freedom between constrained and non-constrained models is 1.00, and the difference between $\chi 2$ is below the level of $3.84(p<0.05)$. It is described as a fully mediating factor if the path that does not go through the parameter appears unparalleled. On the other hand, $\chi 2$ difference between the two models is 3.84 or higher $(p<0.05)$. If the predicted path is entirely significant, then it becomes a partially mediating factor. Finally, the bootstrapping method with 5000 sub-samples (confidence intervals $=95 \%$ ) was performed [80] to examine the significance of the indirect effects. Tables 6 and 7 indicate the results of testing the mediating role of perceived risks and trust in the structural model.

The mediating effect of perceived risks and trust between benefits and online FRS was found in seven paths (see Table 7). The analysis of structural equations on paths of wearing at right TPO-financial risk-usage intention revealed that the $\chi^{2}$ difference between constrained models and the non-contractual model of independent variable and dependent variable path was 6.84 , indicating 3.84 or more $(p<0.05)$. It was found that wearing at right TPO and usage intention route (b) were significantly represented by $t=2.34(p<0.01)$, other routes $(a, c)$ were significantly represented, and financial risk was partially mediated. Considering the indirect effect of wearing at right TPO through financial risk ( $\beta=-0.03$, $p<0.01$ ), it was found that the benefit of wearing at right TPO directly influences usage intention, so financial risk is partially mediated between wearing at right TPO and usage intentions towards online FRS. The higher the benefit of wearing at right TPO, the lower the financial risks, which increases the total effect compared to the direct effect that led to the intention to use online FRS. The analysis of structural equations on paths of reasonable cost-financial risk-usage intention revealed that the $\chi^{2}$ difference between constrained models and non-contractual model of independent variable and dependent variable path was 2.89, indicating less than $3.84(p<0.05)$. It was found that the reasonable cost and usage intention route $(b)$ were not significantly represented by $t=1.02$, other routes $(a$, c) were significantly represented, and financial risk was fully mediated. Considering the indirect effect of reasonable cost through financial risk $(\beta=-0.16, p<0.01)$, it was found that he benefit of reasonable cost did not influence usage intention directly, so financial risk 
is fully mediated between reasonable cost benefit and usage intentions towards online FRS. The higher the benefit of reasonable cost, the lower the financial risk, which increases the total effect compared to the direct effect that led to the intention to use online FRS.

Table 7. Results of mediating effects.

\begin{tabular}{|c|c|c|c|c|c|c|}
\hline $\begin{array}{l}\text { Mediating } \\
\text { var. }\end{array}$ & Path & $\begin{array}{l}\text { Constrained } \\
\text { Model } \chi^{2}\end{array}$ & $\begin{array}{l}\text { Unconstrained } \\
\text { Model } \chi^{2}\end{array}$ & $\begin{array}{l}\text { Differences } \\
\text { of } \chi^{2^{a}}\end{array}$ & $\begin{array}{l}\text { Indirect } \\
\text { effects }\end{array}$ & $\begin{array}{c}\text { Mediation } \\
\text { Effect }\end{array}$ \\
\hline \multirow{2}{*}{ Financial risk } & $\begin{array}{c}\text { Wearing at right } \mathrm{TPO}(\mathrm{X}) \rightarrow \\
\text { Financial risk }(\mathrm{M}) \rightarrow \\
\text { Intention }(\mathrm{Y})\end{array}$ & $79.30(25)$ & $72.29(24)$ & 7.01 & $-0.03^{* *}$ & Partial \\
\hline & $\begin{array}{c}\text { Reasonable cost }(\mathrm{X}) \rightarrow \\
\text { Financial risk }(\mathrm{M}) \rightarrow \\
\text { Intention }(\mathrm{Y})\end{array}$ & $140.76(25)$ & $137.87(24)$ & 2.89 & $-0.16^{* *}$ & Full \\
\hline \multirow{2}{*}{$\begin{array}{l}\text { Performance } \\
\text { risk }\end{array}$} & $\begin{array}{c}\text { Product variety }(\mathrm{X}) \rightarrow \\
\text { Performance risk }(\mathrm{M}) \rightarrow \\
\text { Intention }(\mathrm{Y})\end{array}$ & $77.24(25)$ & $75.31(24)$ & 1.93 & $-0.18 *$ & Full \\
\hline & $\begin{array}{l}\text { Reasonable cost }(\mathrm{X}) \rightarrow \\
(\mathrm{M}) \rightarrow \text { Intention }(\mathrm{Y})\end{array}$ & $57.33(25)$ & $56.95(24)$ & 2.38 & $-0.15^{* *}$ & Full \\
\hline \multirow{3}{*}{ Trust } & $\begin{array}{l}\text { Reasonable cost }(\mathrm{X}) \rightarrow \\
\text { Trust }(\mathrm{M}) \rightarrow \text { Intention }(\mathrm{Y})\end{array}$ & $79.22(25)$ & $76.94(24)$ & 2.28 & $0.31 *$ & Full \\
\hline & $\begin{array}{l}\text { Style conformity }(\mathrm{X}) \rightarrow \\
\text { Trust }(\mathrm{M}) \rightarrow \text { Intention }(\mathrm{Y})\end{array}$ & $55.84(18)$ & $52.61(17)$ & 3.23 & $0.39 *$ & Full \\
\hline & $\begin{array}{c}\text { Product variety }(\mathrm{X}) \rightarrow \\
\text { Trust }(\mathrm{M}) \rightarrow \text { Intention }(\mathrm{Y})\end{array}$ & $45.28(25)$ & $43.68(24)$ & 1.60 & 0.35 * & Full \\
\hline
\end{tabular}

Note: ${ }^{\text {a }}$. Differences of $\chi^{2}$ between constrained model and unconstrained model; ${ }^{*} p<0.05,{ }^{* *} p<0.01$.

The path of product variety-performance risk-usage intention showed that the $\chi^{2}$ difference between constrained models and non-contractual model was 1.93, indicating less than $3.84(p<0.05)$. It was found that product variety and usage intention route (b) were not significantly represented by $t=1.02$, other routes $(a, c)$ were significantly represented, and performance risk was fully mediated. Considering the indirect effect of product variety through performance risk $(\beta=-0.16, p<0.01)$, it was found that the benefit of product variety did not influence usage intention directly, so performance risk is fully mediated between product variety benefit and usage intentions towards online FRS. The higher the benefit of product variety, the lower the performance risk, which enhances the total effect compared to the direct effect that led to the intention to use online FRS. The analysis of structural equations on paths of reasonable cost-performance risk-usage intention revealed that the $\chi 2$ difference between constrained models and non-contractual model was 2.38, indicating less than $3.84(p<0.05)$. It was found that reasonable cost and usage intention route $(b)$ were not significantly represented by $t=1.02$, other routes $(a, c)$ were significantly represented, and performance risk was fully mediated. Considering the indirect effect of reasonable cost through performance risk $(\beta=-0.16, p<0.01)$, it was found that benefit of reasonable cost did not influence usage intention directly, so performance risk is fully mediated between reasonable cost benefit and usage intentions towards online FRS. The higher the benefit of reasonable cost, the lower the performance risk, which increases the total effect compared to the direct effect that led to the intention to use online FRS.

The analysis of structural equations on paths of three benefit factors (i.e., economic relationality, style conformity, and product variety)-trust-usage intention revealed that the $\chi^{2}$ difference between constrained models and non-contractual model path was less than $3.84(p<0.05)$. It was found that benefit variables and usage intention route (b) was not significant, other routes $(\mathrm{a}, \mathrm{c})$ were significantly represented, and trust was fully mediated (see Table 8). Considering the indirect effect of benefits (i.e., economic relationality, style conformity, and product variety) through trust, it was found that benefit did not influence usage intention directly, so trust was fully mediated between benefit (i.e., economic 
relationality, style conformity, and product variety) and usage intentions towards online FRS. The higher the benefit of reasonable cost, style conformity, and product variety, the higher the trust, which improves the total effect compared to the direct effect that led to the intention to use online FRS. Several independent variables (benefits) showed indirect effects through mediating roles of perceived risk and trust on usage intention towards online FRS, thus, providing partial support for Hypotheses 6 and 7.

Table 8. Path analysis for analyzing mediating roles of perceived risk and trust in the relationship between benefits and usage intention of online FRS.

\begin{tabular}{|c|c|c|c|c|c|}
\hline Mediating Variable & Structural Paths & Estimates & S.E. & $T$ & Path Label \\
\hline \multirow{3}{*}{ Financial risk } & $\mathrm{TPO}(\mathrm{X}) \rightarrow \mathrm{FR}(\mathrm{M})$ & 0.23 & 0.04 & $3.44^{* * *}$ & a \\
\hline & TPO $(\mathrm{X}) \rightarrow$ Intention $(\mathrm{Y})$ & 0.25 & 0.04 & $2.34 * *$ & $\mathrm{~b}$ \\
\hline & FR $(\mathrm{M}) \rightarrow$ Intention $(\mathrm{Y})$ & -0.38 & 0.06 & $-5.85^{* * *}$ & c \\
\hline \multirow{3}{*}{ Financial risk } & $\mathrm{ER}(\mathrm{X}) \rightarrow \mathrm{FR}(\mathrm{M})$ & 0.20 & 0.05 & $2.96^{* *}$ & $\mathrm{a}$ \\
\hline & ER $(X) \rightarrow$ Intention $(Y)$ & 0.08 & 0.06 & 1.02 (N.S.) & $\mathrm{b}$ \\
\hline & FR $(\mathrm{M}) \rightarrow$ Intention $(\mathrm{Y})$ & -0.34 & 0.13 & $-3.72 * * *$ & c \\
\hline \multirow{3}{*}{ Performance risk } & $\mathrm{PV}(\mathrm{X}) \rightarrow \mathrm{PR}(\mathrm{M})$ & 0.21 & 0.02 & $3.56^{* * *}$ & a \\
\hline & PV $(\mathrm{X}) \rightarrow$ Intention $(\mathrm{Y})$ & 0.08 & 0.06 & 1.34 (N.S.) & $\mathrm{b}$ \\
\hline & PR (M) $\rightarrow$ Intention (Y) & -0.29 & 0.13 & $-3.23^{* * *}$ & c \\
\hline \multirow{3}{*}{ Performance risk } & $\mathrm{ER}(\mathrm{X}) \rightarrow \mathrm{PR}(\mathrm{M})$ & 0.20 & 0.05 & $3.11^{* * *}$ & $\mathrm{a}$ \\
\hline & ER $(\mathrm{X}) \rightarrow$ Intention $(\mathrm{Y})$ & 0.16 & 0.03 & 1.50 (N.S.) & $\mathrm{b}$ \\
\hline & PR $(\mathrm{M}) \rightarrow$ Intention $(\mathrm{Y})$ & -0.48 & 0.17 & $-3.75^{* * *}$ & c \\
\hline \multirow{3}{*}{ Trust } & $\mathrm{ER}(\mathrm{X}) \rightarrow$ Trust $(\mathrm{M})$ & 0.20 & 0.05 & $3.86^{* * *}$ & a \\
\hline & ER $(\mathrm{X}) \rightarrow$ Intention $(\mathrm{Y})$ & 0.12 & 0.06 & 1.56 (N.S) & $\mathrm{b}$ \\
\hline & Trust $(\mathrm{M}) \rightarrow$ Intention $(\mathrm{Y})$ & 0.36 & 0.10 & $3.33^{* * *}$ & c \\
\hline \multirow{3}{*}{ Trust } & $\mathrm{SC}(\mathrm{X}) \rightarrow$ Trust $(\mathrm{M})$ & 0.26 & 0.05 & $4.18^{* * *}$ & a \\
\hline & $\mathrm{SC}(\mathrm{X}) \rightarrow$ Intention $(\mathrm{Y})$ & 0.11 & 0.06 & 1.12 (N.S.) & $\mathrm{b}$ \\
\hline & Trust $(\mathrm{M}) \rightarrow$ Intention $(\mathrm{Y})$ & 0.32 & 0.15 & $3.17^{* * *}$ & c \\
\hline \multirow{3}{*}{ Trust } & PV $(X) \rightarrow$ Trust $(\mathrm{M})$ & 0.35 & 0.07 & $3.31 * *$ & a \\
\hline & PV $(\mathrm{X}) \rightarrow$ Intention $(\mathrm{Y})$ & 0.12 & 0.09 & 1.17 (N.S.) & $\mathrm{b}$ \\
\hline & Trust $(\mathrm{M}) \rightarrow$ Intention (Y) & 0.31 & 0.12 & $3.68^{* * *}$ & c \\
\hline
\end{tabular}

${ }^{*} p<0.05 .{ }^{* *} p<0.05,{ }^{* * *} p<0.001, \mathrm{TPO}=$ Wearing at right TPO; ER = Reasonable cost; PV = Product variety; SC = Style conformity; $\mathrm{FR}=$ Financial risk; $\mathrm{PR}=$ Performance risk; $\mathrm{SR}=$ Social risk; N.S. = Not significant.

\section{Discussion and Conclusions}

This study contributes to establishing a theoretical model regarding determinants that affect the consumers' usage intention towards online fashion rental services through several dimensions, including the benefits and perceived risks of online FRS that can be motivators or barriers. The result of this study helps in understanding the applied cases of fashion sharing marketing and consumer perception, so that the cooperative consumption process that is achieved via fashion consumers, companies, or other consumers can be established as a positive model for sustainable consumption. This can help fashion rental services companies to implement marketing and communication strategies.

The study also helps to grasp consumers' perception of the fashion sharing economy globally, which is a foundation for promoting a shared economy in the fashion sector. There is a willingness to use fashion sharing economy services. In order to link these services to actual use, a communication strategy for online FSR should be devised to maximize positive factors including reasonable cost, such as cost saving, product collections and trendy styles, and to minimize negative factors which deter consumers, such as financial, 
performance, and social risks. To improve consumers' intention to use fashion sharing economy services, product planning strategies should be implemented, such as rational sharing conditions, provision of various products, and proposals for fashion items and styling that follow the latest trends.

In this study, the fashion sharing economy was divided into donation, second-hand services, and rental services. Furthermore, types and characteristics of each aspect were examined according to the sharing/exchange continuum suggested by Habibi et al. [10]. In previous studies, research was conducted separately, but in this study the types of fashion sharing economy and their characteristics were examined to present an accurate marketing guide. Since fashion donation companies are close to pure sharing, there is a need to approach consumers by grasping characteristics such as social links, or love and caring. This will also require careful marketing access as second-hand companies have both pure sharing and pure exchange characteristics. Finally, recently emerging fashion rental services companies have more pure exchange characteristics than the previous two types. Therefore, it is necessary to present a marketing strategy that is appropriate for identifying characteristics such as reciprocity and calculation.

It has been identified that there are various consumer benefits of fashion rental services. Few studies have been done on the perceived benefits of existing fashion rental services, and several studies have shown financial risk, performance risk, psychological risk, and social risk $[43,51,58]$. Perceived benefits similar to those of other sharing economies were found, and suitability in the fashion domain existed only in the study of Shim and Kim [52]. Thus, in this study, in addition to economy and enjoyment, the aspects considered suitable for the fashion domain, "wearing at right TPO," "product variety," and "space saving", were additionally confirmed. In order to improve consumers' intention to use fashion rental services, it is necessary to have a rational economic strategy, such as presenting reasonable sharing conditions, and a product planning strategy, such as TPO coordination proposals, that match the wearing situation and the collection of products.

In order to make consumers continue to use a service, there must be perceived benefit, but more importantly the perceived risk that hinders the use must be reduced. In this study, consumers showed intention to use due to perceived benefit, but their intention to use decreased as all perceived risks, such as economic risk and product quality risk, were mediated. This can be stated in the context of prospect theory [36]. In other words, consumers are more responsive to the risk of loss than of gain, so fashion rental service companies should examine risk minutely. In addition, as shown in various mediated studies of trust in the sharing economy [38-41], consumers can further strengthen their intention to use if they have trust. Thus, fashion rental service companies should instill confidence in consumers while reducing risk factors so that they can be used continuously rather than just once.

In conclusion, there is an intention to use fashion sharing services, and in order to connect this to actual use, it is necessary to maximize positive factors such as resource saving. A brand strategy should be devised to minimize negative factors such as concerns over consumer damage. That is, a marketing strategy emphasizing "taste consumption" that leads to maximum utility for least payment is needed. The 2030 generation, which values experience more than owning, may approach this in a way that puts greater value on renting and experiencing, without necessarily purchasing.

The implications of this research are as follows. First, it identifies the sub-dimension of the perceived benefits of fashion rental services that have not been examined before. Although various studies on the sharing economy are being conducted, the perceived benefit of these has been insufficient in the continuously growing fashion rental service industry; therefore, this research will be helpful in future studies. In particular, by grasping the sub-dimension of wearing suitability, the characteristics of the fashion domain could be further strengthened. Second, in previous studies, perceived risk was measured in juxtaposition with perceived benefit, but in this study, it was examined via mediation. Consumers can react sequentially rather than recognizing the perceived benefit and perceived risk at 
the same time. Therefore, since this study examined the consumers' decision process in more detail as the mediating effect of perceived risk, this research can be helpful in the future. Third, there is no research on the types and characteristics of the existing fashion sharing economy. Based on the analysis of the sharing economy by Belk and Habibi $[6,10]$, this was applied to the fashion sharing economy. The fashion sharing economy was divided into donation, second-hand, and rental, and characteristics of each aspect were identified. Moreover, if future research is clearly directed and based on this, it would help companies to develop appropriate marketing strategies. Finally, a suitable marketing direction for fashion rental service companies is suggested. Managing perceived risks to strengthen trust will lead to consumer loyalty and increase sales. In addition, even if it is not a fashion rental service, the intention to use is increased just by experiencing a different sharing economy, so if a marketing strategy is pursued through collaboration with other parts of the sharing economy, synergy effects can occur for both companies.

In view of the limitations of this study, additional research guidelines are recommended. The survey was conducted on female consumers in their $20 \mathrm{~s}$ and $30 \mathrm{~s}$ in metropoli$\tan$ areas, so there is a problem with the representativeness of the quantitative research samples. The research should progress through nationwide sampling and comparison by gender and age group. This research has limited itself to pursuing benefits, perceived risk factors, and trust as variables influencing collaborative fashion consumption services and suggests adding various social and cultural factors (consumption value, fashion lifestyle, shopping tendency, etc.) for consumers in the future. Third, the sharing/exchange continuum in the fashion sharing economy was not analyzed through empirical research but through the analysis of previous studies. In future studies, it is necessary to empirically examine this as the sharing/exchange continuum. Finally, fashion rental service companies did not include luxury rental services. Thus, future comparison between a luxury rental study and the findings from this study will deepen our understanding. Additionally, this study conducted quantitative research using an online survey, without any in-depth discussion among respondents. In further research, a qualitative methodology, such as in-depth interviews or focus group interviews, can be attained.

Author Contributions: All authors have worked closely together on conceptualization, methodology, formal analysis, investigation, data curation, original draft preparation, and writing and editing. All authors have read and agreed to the published version of the manuscript.

Funding: This work was supported by the Ministry of Education of the Republic of Korea and the National Research Foundation of Korea (NRF 2019S1A5A2A03054508).

Conflicts of Interest: The authors declare no conflict of interest.

\section{References}

1. Being Human in 2030. Available online: https://www.newagebd.net/article/121252/being-human-in-2030 (accessed on 11 November 2020).

2. The Sharing Economy Could Bring New Business Model to CEE. Available online: https://emerging-europe.com/voices/thesharing-economy-could-bring-new-business-models-to-cee/ (accessed on 11 November 2020).

3. Hamari, J.; Sjöklint, M.; Ukkonen, A. The sharing economy: Why people participate in collaborative consumption. JASIS J. Assoc. Inf. Sci. Technol. 2016, 67, 2047-2059. [CrossRef]

4. Codagnone, C.; Martens, B. Scoping the sharing economy: Origins, definitions, impact and regulatory issues. SSRN Electr. J. 2016, 1. [CrossRef]

5. Lessig, L. Remix: Making Art and Commerce Thrive in the Hybrid. Economy; Penguin Press: New York, NY, USA, 2008 ; p. 143.

6. Belk, R. Sharing versus pseudo-sharing in Web 2.0. Anthropologist 2014, 18, 7-23. [CrossRef]

7. Rental Fashion: A Sharing Economy. Available online: https://3dinsider.optitex.com/rentable-fashion-sharing-economy/ (accessed on 11 November 2020).

8. The Power of the Fashion Rental Revolution. Available online: https://www.raconteur.net/retail/fashion-rental-revolution/ (accessed on 11 November 2020).

9. Korea P\&G-Korea Zero Waste Movement Network Announces Results of Consumer Sustainability Survey. Available online: http:/ / isplus.live.joins.com/news/article/article.asp?total_id=23809443 (accessed on 11 November 2020). 
10. Habibi, M.R.; Davidson, A.; Laroche, M. What managers should know about the sharing economy. Bus. Horiz. 2017, 60, 113-121. [CrossRef]

11. Petruzzi, M.A.; Sheppard, V.; Marques, C. Positioning Airbnb and Fairbnb in the sharing-exchange continuum. Curr. Issues. Tour. 2019, 1-4. [CrossRef]

12. Sanasi, S.; Ghezzi, A.; Cavallo, A.; Rangone, A. Making sense of the sharing economy: A business model innovation perspective. Technol. Anal. Strat. Manag. 2020, 32, 895-909. [CrossRef]

13. Lim, W.M.; Yap, S.F.; Makkar, M. Home sharing in marketing and tourism at a tipping point: What do we know, how do we know, and where should we be heading? J. Bus. Res. 2020, 122, 534-566. [CrossRef]

14. Li, Y.; Ding, R.; Cui, L.; Lei, Z.; Mou, J. The impact of sharing economy practices on sustainability performance in the Chinese construction industry. Res. Conserv. Recycl. 2019, 150, 104409. [CrossRef]

15. Ciulli, F.; Kolk, A. Incumbents and business model innovation for the sharing economy: Implications for sustainability. J. Clean. Prod. 2019, 214, 995-1010. [CrossRef]

16. Laukkanen, M.; Tura, N. The potential of sharing economy business models for sustainable value creation. J. Clean. Prod. 2020, 253, 120004. [CrossRef]

17. Degenstein, L.; McQueen, R.H.; McNeill, L.; Hamlin, R.; Wakes, S.J.; Dunn, L.A. Impact of physical condition on disposal and end-of-life extension of clothing. Int. J. Consum. Stud. 2020, 44, 586-596. [CrossRef]

18. Patwary, S. Consumer Clothing Behavior and Associated Environmental Impact. Preprints 2019, 2019090143. [CrossRef]

19. Joung, H.M.; Park-Poaps, H. Factors motivating and influencing clothing disposal behaviours. Int. J. Consum. Stud. 2013, 37, 105-111. [CrossRef]

20. Lai, C.C.; Chang, C.E. Clothing disposal behavior of Taiwanese consumers with respect to environmental protection and sustainability. Sustainability 2020, 12, 9445. [CrossRef]

21. Bianchi, C.; Birtwistle, G. Sell, give away, or donate: An exploratory study of fashion clothing disposal behaviour in two countries. Inter. Rev. Retail Distrib. Consum. Res. 2010, 20, 353-368. [CrossRef]

22. Lee, J.Y.; Halter, H.; Johnson, K.K.; Ju, H. Investigating fashion disposition with young consumers. Young Consum. 2013, 14, 67-78.

23. Cruz-Cárdenas, J.; González, R.; Gascó, J. Clothing disposal system by gifting: Characteristics, processes, and interactions. Cloth Tex. Res. J. 2017, 35, 49-63. [CrossRef]

24. Ferraro, C.; Sands, S.; Brace-Govan, J. The role of fashionability in second-hand shopping motivations. J. Retail. Consum. Serv. 2016, 32, 262-268. [CrossRef]

25. Zaman, M.; Park, H.; Kim, Y.K.; Park, S.H. Consumer orientations of second-hand clothing shoppers. J. Glob. Fash. Mark. 2019, 10, 163-176. [CrossRef]

26. Zampier, R.L.; Rita de Cássia, P.F.; Pinto, M.R. Authenticity in Discursive Practices of the Online Market for Second-Hand Luxury Clothing. Qual. Rep. 2019, 24, 3125-3149.

27. Hur, E. Rebirth fashion: Secondhand clothing consumption values and perceived risks. J. Clean. Prod. 2020, 273, 122951. [CrossRef]

28. Ek Styvén, M.; Mariani, M.M. Understanding the intention to buy secondhand clothing on sharing economy platforms: The influence of sustainability, distance from the consumption system, and economic motivations. Psych. Mark. 2020, 37, 724-739. [CrossRef]

29. Laitala, K.; Klepp, I.G. Motivations for and against second-hand clothing acquisition. Cloth. Cult. 2018, 5, 247-262. [CrossRef]

30. Matthews, D.; Hodges, N.N. Clothing swaps: An exploration of consumer clothing exchange behaviors. Fam. Consum. Sci. Res. J. 2016, 45, 91-103. [CrossRef]

31. Connell, K.Y.H. Exploration of Second-Hand Apparel Acquisition Behaviors and Barriers. In Proceedings of the International Apparel and Textile Association Annual Conference, Bellevue, WA, USA, 28-31 October 2009.

32. Akbar, P.; Mai, R.; Hoffmann, S. When do materialistic consumers join commercial sharing systems. J. Bus. Res. 2016, 69, 4215-4224. [CrossRef]

33. Ruan, Y.; Xu, Y. Consumer Behavior toward Luxury Fashion Rental: A Hierarchical Motivations Approach. In Proceedings of the International Textile and Apparel Association Annual Conference, Cleveland, OH, USA, 1 January 2018.

34. Lang, C.; Li, M.; Zhao, L. Understanding consumers' online fashion renting experiences: A text-mining approach. Sustain. Prod. Consum. 2020, 21, 132-144. [CrossRef]

35. Peter, J.P.; Tarpey, L.X., Sr. A comparative analysis of three consumer decision strategies. J. Consum. Res. 1975, 2, 29-37. [CrossRef]

36. Tversky, A.; Kahneman, D. Advances in prospect theory: Cumulative representation of uncertainty. J. Risk Uncertain. 1992, 5, 297-323. [CrossRef]

37. Schoorman, F.D.; Mayer, R.C.; Davis, J.H. Organizational trust: Philosophical perspectives and conceptual definitions. Acad. Manag. Rev. 1996, 21, 337-340.

38. Ter Huurne, M.; Ronteltap, A.; Corten, R.; Buskens, V. Antecedents of trust in the sharing economy: A systematic review. J. Consum. Behav. 2017, 16, 485-498. [CrossRef]

39. Kuswanto, A.; Sundari, S.; Harmadi, A.; Hariyanti, D.A. The determinants of customer loyalty in the Indonesian ride-sharing services: Offline vs. online. Innov. Manag. Rev. 2019, 17, 75-85. [CrossRef]

40. Wan, X.; Zhao, H.; Wang, T.; Zhang, W. Trust mediates the effect of positive facial expressions on rental intention when using accommodation-sharing platforms. Soc. Behav. Personal. Int. J. 2020, 48, 1-11. [CrossRef] 
41. Ye, S.; Lei, S.I.; Shen, H.; Xiao, H. Social presence, telepresence and customers' intention to purchase online peer-to-peer accommodation: A mediating model. J. Hospit. Tour. Manag. 2020, 42, 119-129. [CrossRef]

42. Cui, F.; Lin, D.; Qu, H. The impact of perceived security and consumer innovativeness on e-loyalty in online travel shopping. J. Trav. Tour. Mark. 2018, 35, 819-834. [CrossRef]

43. Nadeem, W.; Khani, A.H.; Schultz, C.D.; Adam, N.A.; Attar, R.W.; Hajli, N. How social presence drives commitment and loyalty with online brand communities? the role of social commerce trust. J. Retail. Consum. Serv. 2020, 55, 102136. [CrossRef]

44. Thaler, R. Mental accounting and consumer choice. Mark. Sci. 1985, 4, 199-214. [CrossRef]

45. Grewal, D.; Nonroe, K.B.; Krishnan, R. The effect of price-comparison advertising on buyers' perceptions of acquisition value, transaction value, and behavioral intentions. J. Mark. 1998, 62, 46-59.

46. Roos, D.; Hahn, R. Does shared consumption affect consumers' values, attitudes, and norms? A panel study. J. Bus. Res. 2017, 77, 113-123. [CrossRef]

47. Stollery, A.; Jun, S.H. The antecedents of perceived value in the Airbnb context. Asia Pac. J. Innov. Entrep. 2017, 11, 391-404. [CrossRef]

48. Ye, S.; Ying, T.; Zhou, L.; Wang, T. Enhancing customer trust in peer-to-peer accommodation: A "soft" strategy via social presence. Int. J. Hosp. Manag. 2019, 79, 1-10. [CrossRef]

49. Lu, K.; Wang, X. Analysis of Perceived Value and Travelers' Behavioral Intention to Adopt Ride-Hailing Services: Case of Nanjing, China. J. Adv. Transp. 2020, 13, 4380610. [CrossRef]

50. Lee, Z.W.; Chan, T.K.; Balaji, M.S.; Chong, A.Y.L. Why people participate in the sharing economy: An empirical investigation of Uber. Int. Res. 2018, 28, 829-850. [CrossRef]

51. Lang, C.; Seo, S.; Liu, C. Motivations and obstacles for fashion renting: A cross-cultural comparison. J. Fash. Mark. Manag. 2019, 23, 519-536. [CrossRef]

52. Shim, J.; Kim, Y. A study on the benefits sought and the rental intention according to rental clothing experience. Korean J. Hum. Ecol. 2004, 13, 599-607.

53. Zhang, G.; Wang, L.; Shi, P. Research on Sharing Intention Formation Mechanism Based on the Burden of Ownership and Fashion Consciousness. Sustainability 2019, 11, 992. [CrossRef]

54. Mukendi, A.; Henninger, C.E. Exploring the spectrum of fashion rental. J. Fash. Mark. Manag. 2020, 24, 455-469. [CrossRef]

55. Kathan, W.; Matzler, K.; Veider, V. The sharing economy: Your business model's friend or foe? Bus. Horiz. 2016, 59, 663-672. [CrossRef]

56. Tu, J.C.; Hu, C.L. A Study on the Factors Affecting Consumers' Willingness to Accept Clothing Rentals. Sustainability 2018, 10, 4139. [CrossRef]

57. Mitchell, V.W. Consumer perceived risk: Conceptualisations and models. Eur. J. Mark. 1999, 33, 163-195. [CrossRef]

58. Youn, S.Y.; Lee, K.H. Proposing value-based technology acceptance model: Testing on paid mobile media service. Fash. Tex. 2019, 6,1-16. [CrossRef]

59. Lang, C. Perceived risks and enjoyment of access-based consumption: Identifying barriers and motivations to fashion renting. Fash. Tex. 2018, 5, 23. [CrossRef]

60. $\mathrm{Xu}, \mathrm{X}$. How do consumers in the sharing economy value sharing? Evidence from online reviews. Decis. Support Syst. 2020, 128, 113-162. [CrossRef]

61. Belk, R.W. Possessions and the extended self. J. Consum. Res. 1988, 15, 139-168. [CrossRef]

62. Baek, E.; Oh, G.E.G. Diverse values of fashion rental service and contamination concern of consumers. J. Bus. Res. 2020, 123, 165-175. [CrossRef] [PubMed]

63. Catulli, M. What uncertainty? Further insight into why consumers might be distrustful of product service systems. J. Manuf. Technol. Manag. 2012, 23, 780-793. [CrossRef]

64. Akram, M.S.; Malik, A.; Shareef, M.A.; Goraya, M.A.S. Exploring the interrelationships between technological predictors and behavioral mediators in online tax filing: The moderating role of perceived risk. Gov. Inf. Q. 2019, 36, 237-251. [CrossRef]

65. Wang, Y.; Gu, J.; Wang, S.; Wang, J. Understanding consumers' willingness to use ride-sharing services: The roles of perceived value and perceived risk. Transp. Res. Part C Emerg. Technol. 2019, 105, 504-519. [CrossRef]

66. Casidy, R.; Wymer, W. A risk worth taking: Perceived risk as moderator of satisfaction, loyalty, and willingness-to-pay premium price. J. Retail. Consum. Serv. 2016, 32, 189-197. [CrossRef]

67. Mortimer, G.; Fazal e Hasan, S.; Andrews, L.; Martin, J. Online grocery shopping: The impact of shopping frequency on perceived risk. Int. Rev. Retail. Distrib. Consum. Res. 2016, 26, 202-223. [CrossRef]

68. Martin, C.J.; Upham, P. Grassroots social innovation and the mobilization of values in collaborative consumption: A conceptual model. J. Clean. Prod. 2016, 134, 204-213. [CrossRef]

69. Möhlmann, M. Collaborative consumption: Determinants of satisfaction and the likelihood of using a sharing economy option again. J. Consum. Behav. 2015, 14, 193-207. [CrossRef]

70. Bhatti, A.; Ur Rahman, S. Perceived benefits and perceived risks effect on online shopping behavior with the mediating role of consumer purchase intention in Pakistan. Int. J. Manag. Stud. 2019, 26, 33-54.

71. Papadopoulou, P.; Andreou, A.; Kanellis, P.; Martakos, D. Trust and relationship building in electronic commerce. Int. Res. 2001, 11, 322-332. [CrossRef] 
72. Ajzen, I. Constructing a TPB Questionnaire: Conceptual and Methodological Considerations. Available online: http://www. unibielefeld.de/ikg/zick/ajzen\%20construction\%20a\%20tpb\%20questionnaire.pdf (accessed on 19 June 2020).

73. Edbring, E.G.; Lehner, M.; Mont, O. Exploring consumer attitudes to alternative models of consumption: Motivations and barriers. J. Clean. Prod. 2016, 123, 5-15. [CrossRef]

74. Pedersen, E.R.G.; Netter, S. Collaborative consumption: Business model opportunities and barriers for fashion libraries. J. Fash. Mark. Manag. 2015, 19, 258-273. [CrossRef]

75. Piscicelli, L.; Cooper, T.; Fisher, T. The role of values in collaborative consumption: Insights from a product-service system for lending and borrowing in the UK. J. Clean. Prod. 2015, 97, 21-29. [CrossRef]

76. Schumacker, R.E.; Lomax, R.G. A Beginner's Guide to Structural Equation Modeling, 2nd ed.; Lawrence Erlbaum Associates: Mahwah, NJ, USA, 2004.

77. Hair, J.F.; Black, W.C.; Babin, B.J.; Anderson, R.E. Multivariate Data Analysis: International Version, 7th ed.; Pearson: Hoboken, NJ, USA, 2020.

78. Fornell, C.; Larcker, D.F. Structural equation models with unobservable variables and measurement error: Algebra and statistics. J. Mark. Res. 1981, 18, 382-388. [CrossRef]

79. Cohen, J.; Cohen, P.; West, S.G.; Aiken, L.S. Applied Multiple Regression/Correlation Analysis for the Behavioral Sciences, 3rd ed.; Lawrence Erlbaum Associate Inc: Mahwah, NJ, USA, 2013.

80. Hair, J.F., Jr.; Hult, G.T.M.; Ringle, C.; Sarstedt, M. A Primer on Partial Least Squares Structural Equation Modeling (PLS-SEM), 2nd ed.; Sage Publications: Thousand Oaks, CA, USA, 2017. 